\title{
Molecular Characterization and Comparative Genomics of IncQ-3 Plasmids Conferring Resistance to Various Antibiotics Isolated from a Wastewater Treatment Plant in Warsaw (Poland)
}

\author{
Marta Piotrowska ${ }^{1}$, Lukasz Dziewit $^{2}{ }^{1}$, Rafał Ostrowski ${ }^{1}$, Cora Chmielowska ${ }^{3}$ \\ and Magdalena Popowska ${ }^{1, * \mathbb{D}}$ \\ 1 Department of Bacterial Physiology, Institute of Microbiology, Faculty of Biology, University of Warsaw, \\ 02-096 Warsaw, Poland; m.piotrowska@biol.uw.edu.pl (M.P.); rafalostrowski@biol.uw.edu.pl (R.O.) \\ 2 Department of Environmental Microbiology and Biotechnology, Institute of Microbiology, Faculty of Biology, \\ University of Warsaw, 02-096 Warsaw, Poland; ldziewit@biol.uw.edu.pl \\ 3 Department of Bacterial Genetics, Institute of Microbiology, Faculty of Biology, University of Warsaw, \\ 02-096 Warsaw, Poland; corachmiel@biol.uw.edu.pl \\ * Correspondence: magdapop@biol.uw.edu.pl
}

Received: 1 September 2020; Accepted: 16 September 2020; Published: 17 September 2020

\begin{abstract}
As small, mobilizable replicons with a broad host range, IncQ plasmids are widely distributed among clinical and environmental bacteria. They carry antibiotic resistance genes, and it has been shown that they confer resistance to $\beta$-lactams, fluoroquinolones, aminoglycosides, trimethoprim, sulphonamides, and tetracycline. The previously proposed classification system divides the plasmid group into four subgroups, i.e., IncQ-1, IncQ-2, IncQ-3, and IncQ-4. The last two subgroups have been poorly described so far. The aim of this study was to analyze five newly identified IncQ-3 plasmids isolated from a wastewater treatment plant in Poland and to compare them with all known plasmids belonging to the IncQ-3 subgroup whose sequences were retrieved from the NCBI database. The complete nucleotide sequences of the novel plasmids were annotated and bioinformatic analyses were performed, including identification of core genes and auxiliary genetic load. Furthermore, functional experiments testing plasmid mobility were carried out. Phylogenetic analysis based on three core genes $(\mathrm{rep} A, \mathrm{mobA} / \mathrm{rep} B$, and $m o b C)$ revealed the presence of three main clusters of IncQ-3 replicons. Apart from having a highly conserved core, the analyzed IncQ-3 plasmids were vectors of antibiotic resistance genes, including (I) the qnrS2 gene that encodes fluoroquinolone resistance and (II) $\beta$-lactam, trimethoprim, and aminoglycoside resistance genes within integron cassettes.
\end{abstract}

Keywords: plasmid; IncQ; antibiotic resistance; wastewater treatment plant

\section{Introduction}

In the natural environment, as a result of the presence of subminimal inhibitory concentrations of antibiotics, resistance genes encoded by mobile genetic elements, such as plasmids, transposons, and integrons, can be disseminated through horizontal gene transfer (HGT) [1-6]. Wastewater treatment plants (WWTPs) are the entry routes for antibiotic-resistant bacteria (ARBs), including pathogenic and multidrug-resistant (MDR) strains [7]. As sites where both antibiotics and favorable conditions for bacterial growth occur, WWTPs promote horizontal gene transfer (HGT) $[8,9]$. HGT events may lead to the rapid emergence and dissemination of antibiotic resistance among bacteria both in clinical and natural environments [10] and also to genetic exchange between clinical and WWTP strains [11,12]. 
WWTPs are a reservoir for bacteria harboring antibiotic resistance plasmids. Several studies showed the presence of ARGs in plasmid metagenomes of WWTPs and indicated that ARG profiles of activated sludge and final effluent are highly similar $[13,14]$. The occurrence of a similar gene pool at different stages of wastewater treatment is caused by the fact that antibiotics, especially fluoroquinolones, trimethoprim, or sulfonamides, are poorly removed during the wastewater treatment process. Generally, traditional WWTPs are not tailored for the removal of antibiotics or ARGs [15-17]. Multiple studies revealed the presence of ARGs and ARBs even in wastewater effluents [18-21], which poses a threat to their further dissemination to habitats downstream of the sewage plant [22]. The ARGs detected in WWTPs confer resistance to all major classes of antimicrobial drugs used both in medicine and veterinary medicine, including aminoglycosides, $\beta$-lactams, chloramphenicols, fluoroquinolones, macrolides, rifampicin, tetracyclines, trimethoprim, and sulphonamide [17]. Many of these resistance genes are located on resistance plasmids. Among these plasmids, there is a remarkable variety in size and load of genes either conferring resistance to antibiotics, detergents, heavy metals, or those encoding virulence factors [5].

Plasmids of the IncQ group are small-sized, mobilizable replicons with a broad host range (BHR). Their mechanism of replication relies on strand displacement [23]. This makes the plasmid DNA replication less dependent on the host cell apparatus, enabling their broad host range. An archetype of the IncQ group is the RSF1010 plasmid [24]. Since its identification, many other replicons of the Inc group have been discovered worldwide [25-28]. Previous studies indicated that an evolutionary success of IncQ plasmids in widespread dissemination is a result of their (a) small size, (b) high copy number, (c) ability to replicate in diverse bacterial hosts, and (d) ability to be transferred from one host to another. It was also shown that these plasmids carry various ARGs conferring resistance to aminoglycosides, $\beta$-lactams, carbapenem, chloramphenicol, florfenicol, lincosamides, sulphonamides, streptothricin, tetracyclines, and quinolones [29,30].

Loftie-Eaton and Rawlings [30] proposed to divide this group of plasmids into the following four subgroups: IncQ-1, IncQ-2, IncQ-3, and IncQ-4. Plasmids of the first two groups have been studied in detail compared to those of the IncQ-3 and IncQ-4 subgroups, to which little attention has been paid so far [29,31-33].

The main goal of this study was to perform a meta-analysis of five newly identified IncQ-3 plasmids in the light of general diversity of IncQ-3 replicons. The genomic structure, potential mobility, biogeography, and diversity of antibiotic resistance genes carried by these plasmids were investigated.

\section{Results and Discussion}

\subsection{Structural and Functional Genomics of Five Novel IncQ Plasmids}

In the course of our previous studies, a plethora of $\beta$-lactamase-resistant bacterial strains harboring various extrachromosomal replicons were identified [20,21]. Sequencing of their plasmidomes revealed a group of five small $(7.6-9.6 \mathrm{~kb})$ plasmids that were present in 16 clonally unrelated Gram-negative multireplicon strains. Based on an analysis of their replication systems, the plasmids were classified into the IncQ-3 subgroup. Interestingly, in all 16 strains various sets of plasmids accompanying IncQ-3 replicons were observed, which may exemplify HGT events among bacteria inhabiting the analyzed wastewater treatment plant, as observed previously for other environments [34-36]. Based on their genetic structure and gene load, the identified plasmids were divided into three groups: (i) p5.4_c4 and p115_p2, (ii) p458_p3 and p426_p3, (iii) p435_c4 (Figure 1, Table 1). 


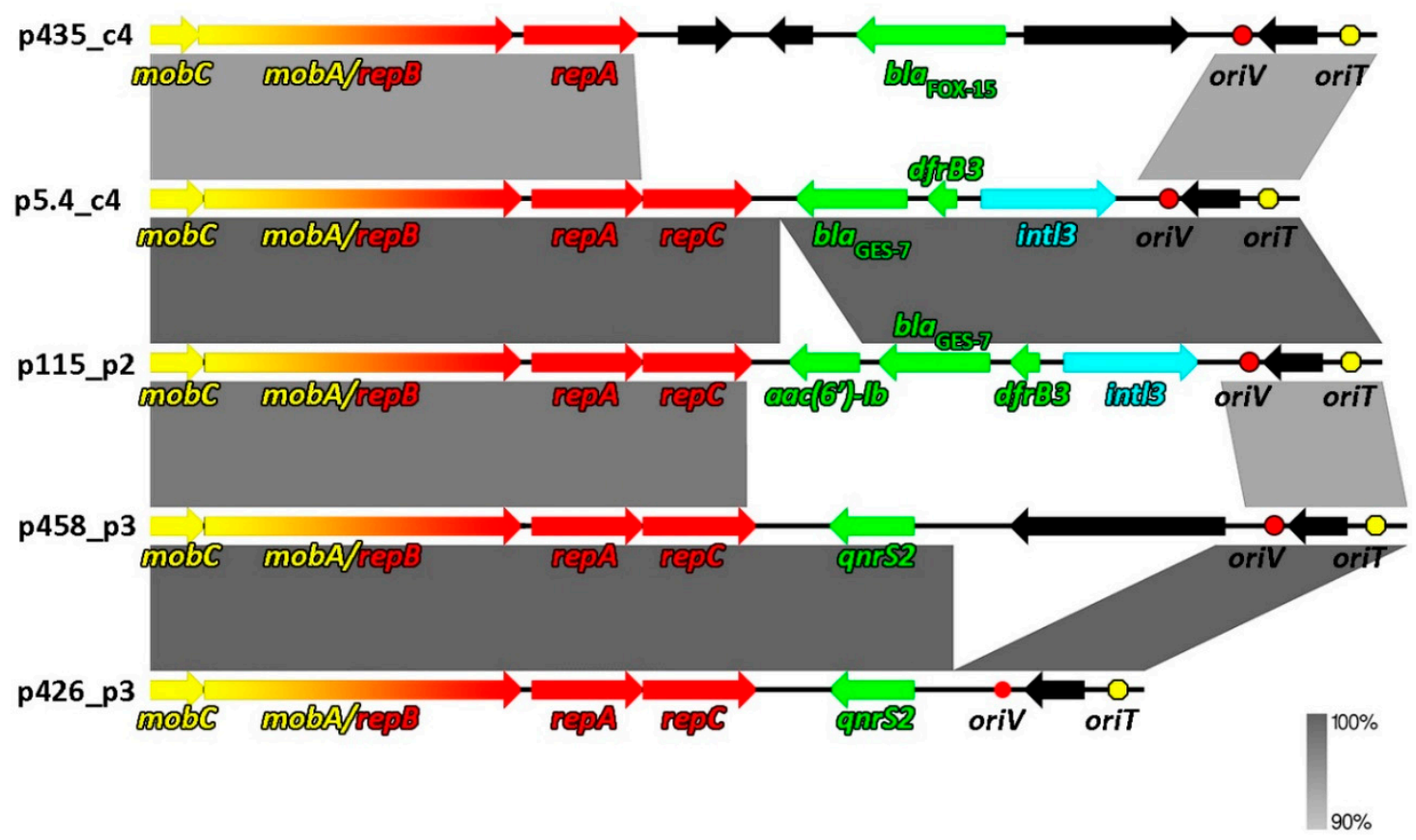

Figure 1. Linear maps showing the genetic structure of the circular IncQ-3 plasmids identified in the study. Genes assigned to specific modules are highlighted in different colors: Yellow-mobilization to plasmid transfer module, red-replication module, green-antibiotic resistance genes, blue-integrase. Red and yellow dots represent oriV and oriT, respectively. Comparative analyses were performed using $90 \%$ nucleotide sequence identity threshold (gray areas connecting DNA regions).

Table 1. General information concerning the IncQ-3 plasmids identified in this study.

\begin{tabular}{|c|c|c|c|c|c|c|c|}
\hline $\begin{array}{l}\text { Plasmid } \\
\text { Name }\end{array}$ & $\begin{array}{l}\text { Plasmid } \\
\text { Size (bp) }\end{array}$ & $\begin{array}{c}\text { GC } \\
\text { Content (\%) }\end{array}$ & $\begin{array}{c}\text { Host Strain } \\
\text { (16S rDNA } \\
\text { GenBank acc. } \\
\text { no.) }\end{array}$ & $\begin{array}{c}\text { Type } \\
\text { of Wastewater }\end{array}$ & $\begin{array}{c}\text { Antibiotic } \\
\text { Resistance Genes }\end{array}$ & $\begin{array}{c}\text { Integron } \\
\text { Integrase Genes }\end{array}$ & $\begin{array}{l}\text { GenBank } \\
\text { Accession } \\
\text { Number }\end{array}$ \\
\hline p5.4_c4 & 8814 & 62 & $\begin{array}{l}\text { Aeromonas sp. } \\
\text { (MF461069, } \\
\text { MF461079) }\end{array}$ & RW & $\begin{array}{l}b^{b l a_{\mathrm{GES}-7}}, \\
d f r B 3\end{array}$ & intI3 & MT231818 \\
\hline p115_p2 & 9448 & 61.5 & $\begin{array}{l}\text { Aeromonas sp. } \\
\text { (MF461085); } \\
\text { Raoultella sp. } \\
\text { (MF457856- } \\
\text { MF457866) }\end{array}$ & RW & $\begin{array}{c}a a c\left(6^{\prime}\right) i b \\
b l a_{\mathrm{GES}-7}, d f r B 3\end{array}$ & intI3 & MT231822 \\
\hline p458_p3 & 9639 & 57 & $\begin{array}{l}\text { Aeromonas sp. } \\
\text { (MF461156) }\end{array}$ & TW & qnrS2 & - & MT231819 \\
\hline p426_p3 & 7621 & 59.7 & $\begin{array}{l}\text { Aeromonas sp. } \\
\text { (MF461154) }\end{array}$ & TW & $q n r S 2$ & - & MT231821 \\
\hline p435_c4 & 9407 & 61.2 & $\begin{array}{l}\text { Kluyvera sp. } \\
\text { (MF457880) }\end{array}$ & AS & $b l a_{\mathrm{FOX}-15}$ & - & MT231820 \\
\hline
\end{tabular}

Footnotes: RW—raw wastewater; AS—activated sludge; TW—-treated wastewater.

Plasmid p5.4_c4 was identified parallelly in two Aeromonas strains, i.e., 5.4 (GenBank: MF461069) and 6.45 (MF461079), which had been isolated from raw wastewater samples. Plasmid p115_p2 was identified in Aeromonas sp. 115, which had been found in raw wastewater and ten Raoutella sp. strains isolated from activated sludge samples, i.e., 210C (MF457856), 274B (MF457859), 213C (MF457857), 382A (MF457862), 293 (MF457865), 385A (MF457863), 299A (MF457866), 376 (MF457861), 286 (MF457864), and 328 (MF457860). Both replicons, i.e., p5.4_c4 and p115_p2, showed high similarity (sequence coverage of $84-100 \%$ and nucleotide sequence identity of $99-100 \%$ ) to four other IncQ-3 plasmids, namely: pPCMI3 (MH569711) from clinical Serratia marcescens strain S89, pJF-789 (KX912254) from 
clinical Klebsiella oxytoca strain H140960789, pEMB2 (KJ631731) from an environmental, uncultured bacterium, and pQ7 (NC_014356) from clinical Escherichia coli strain 7 (Table 2).

Table 2. Summarized information concerning IncQ-3 plasmids retrieved from the GenBank (NCBI) database.

\begin{tabular}{|c|c|c|c|c|c|c|c|}
\hline Plasmid & Size (bp) & Host Strain & Sample Origin & $\begin{array}{c}\text { Antibiotic } \\
\text { Resistance Genes }\end{array}$ & $\begin{array}{l}\text { Integron } \\
\text { Integrase } \\
\text { Genes }\end{array}$ & $\begin{array}{l}\text { GenBank } \\
\text { Accession } \\
\text { Number }\end{array}$ & Reference \\
\hline pPCMI3 & 9448 & $\begin{array}{l}\text { Serratia marcescens subsp. } \\
\text { marcescens } \mathrm{S} 89\end{array}$ & $\begin{array}{l}\text { clinical sample, } \\
\text { urine (Poland) }\end{array}$ & $\begin{array}{c}\left.\text { blaOXA/aac( } 6^{\prime}\right)-I b-c r, \\
\text { bla }\end{array}$ & intI3 & MH569711 & - \\
\hline pJF-789 & 9016 & $\begin{array}{c}\text { Klebsiella oxytoca } \\
\text { H140960789 }\end{array}$ & clinical isolate & $b l a_{\mathrm{GES}-5}, a a c\left(6^{\prime}\right)-l b$ & intI1 & KX912254 & - \\
\hline pEMB2 & 9042 & uncultured bacterium & WWTP (South Korea) & $\begin{array}{c}b l a_{\mathrm{GES}-1} \\
b l a_{\mathrm{OXX}} / a a c\left(6^{\prime}\right)-l b\end{array}$ & intI3 & KJ631731 & [37] \\
\hline pQ7 & 9042 & Escherichia coli 7 & $\begin{array}{c}\text { clinical } \\
\text { sample (Switzerland) }\end{array}$ & $\begin{array}{c}b l a_{\mathrm{GES}-1} \\
b l a_{\mathrm{OXA}} / a a c\left(6^{\prime}\right)-l b\end{array}$ & intI3 & NC_014356 & [32] \\
\hline pJF-707 & 8300 & $\begin{array}{l}\text { Klebsiella oxytoca } \\
\text { H143640707 }\end{array}$ & clinical sample (UK) & $b l a_{\mathrm{GES}-5}$ & intI3 & KX946994 & - \\
\hline pUL3AT & 9005 & Enterobacter cloacae LIM73 & hospital effluent (France) & 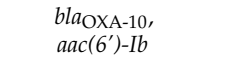 & intI3 & HE616889 & [38] \\
\hline pULIn3-9 & & Citrobacter freundii LIM86 & $\begin{array}{l}\text { hospital effluent } \\
\text { (Luxembourg) }\end{array}$ & $b l a_{\mathrm{OXA}-2}, b l a_{\mathrm{GES}-1}$ & - & - & [39] \\
\hline pAHH04 & 7191 & $\begin{array}{l}\text { Aeromonas hydrophila } \\
\text { SNUFPC-A10 }\end{array}$ & fish (South Korea) & qnrS2 & - & JN315883 & [40] \\
\hline pAB5 & 7212 & Aeromonas caviae AB5 & river water (China) & qurS2 & - & KU644674 & [28] \\
\hline pFECR & 6671 & $\begin{array}{l}\text { uncultured bacterium } \\
\text { clone AA-102 }\end{array}$ & WWTP (Canada) & qnrS2 & - & MF554639 & - \\
\hline pUR19829-KPC21 & 12748 & $\begin{array}{l}\text { Escherichia coli } \\
\text { INSRA19829 }\end{array}$ & clinical sample (Portugal) & qnrS2 & - & MH133192 & [41] \\
\hline pHP5 & 7637 & $\begin{array}{c}\text { Aeromonas } \\
\text { allosaccharophila HP5 }\end{array}$ & $\begin{array}{l}\text { aquatic environment near } \\
\text { hospital (China) }\end{array}$ & qurS2 & - & KU644676 & [28] \\
\hline pHP16 & 8213 & Aeromonas caviae HP16 & $\begin{array}{l}\text { aquatic environment near } \\
\text { hospital (China) }\end{array}$ & qnrS2 & - & KU644675 & [28] \\
\hline pKPSH212 & 7742 & Klebsiella pneитопiae I212 & $\begin{array}{l}\text { WWTP/ reclamation } \\
\text { project site (Israel) }\end{array}$ & qnrS2 & - & KT896501 & [42] \\
\hline pKPSH70 & 7748 & Klebsiella pneuтопіае I70 & $\begin{array}{l}\text { WWTP/ reclamation } \\
\text { project site (Israel) }\end{array}$ & qnrS2 & - & KT896500 & [42] \\
\hline pBRST7.6 & 7621 & Aeromonas hydrophila AO1 & infected fish & qurS2 & - & NC_011207 & [31] \\
\hline pGNB2 & 8469 & - & $\begin{array}{c}\text { activated } \\
\text { sludge (Germany) }\end{array}$ & qnrS2 & - & NC_013773 & [29] \\
\hline pKPSH213.55 & 6981 & Klebsiella pneuтопіае I213 & $\begin{array}{l}\text { WWTP/ reclamation } \\
\text { project site (Israel) }\end{array}$ & qnrS2 & - & KT896502 & [42] \\
\hline pKPSH231 & 7748 & Klebsiella pneuтопіае I231 & $\begin{array}{l}\text { WWTP/ reclamation } \\
\text { project site (Israel) }\end{array}$ & qnrS2 & - & KT896503 & [42] \\
\hline pKPSH169 & 7747 & Klebsiella pneumoniae I169 & $\begin{array}{l}\text { WWTP/ reclamation } \\
\text { project site (Israel) }\end{array}$ & qnrS2 & - & KT896499 & [42] \\
\hline pBF7.8 & 7844 & $\begin{array}{c}\text { Aeromonas } \\
\text { hydrophila IB101 }\end{array}$ & infected fish & qurS2 & - & KM245123 & - \\
\hline unnamed & 7555 & $\begin{array}{c}\text { Salmonella enterica subsp. } \\
\text { enterica serovar } \\
\text { Typhimurium var. 5- } \\
\text { strain } 63\end{array}$ & swine (USA) & qnrS2 & - & MK191840 & - \\
\hline pQnrS2_045523 & 9639 & $\begin{array}{l}\text { Enterobacter kobei } \\
\text { WCHEK045523 }\end{array}$ & clinical sample (China) & qnrS2 & - & СР032896 & - \\
\hline pAER-ba17 & 13512 & Aeromonas sp. ASNIH2 & $\begin{array}{l}\text { USA } \\
\text { from rat gut metagenome }\end{array}$ & - & - & СР026407 & - \\
\hline pRGRH0378 & 5790 & uncultured prokaryote & $\begin{array}{l}\text { metamobilome, hospital } \\
\text { sewer (Denmark) }\end{array}$ & - & - & LN853034 & - \\
\hline
\end{tabular}

Footnotes: WWTP—wastewater treatment plant.

The second group also contained two replicons, i.e., p458_p3 and p426_p3, which were identified within Aeromonas strains 458 (MF461156) and 426 (MF461154), respectively, both isolated from treated wastewater. For both replicons, 16 highly similar plasmid sequences were found in the NCBI database (coverage 70-100\%, identity 97-100\%), namely: pAHH04 (JN315883), pBRST7.6 (NC_011207), and pBF7.8 (KM245123), from three Aeromonas hydrophila strains isolated from infected fish, pAB5 (KU644674) from Aeromonas caviae isolated from a river, pFECR (MF554639) from an uncultured bacterium isolated from wastewater, pUR19829-KPC21 (MH133192) from clinical E. coli INSRA19829, pHP5 (KU644676) from an aquatic strain of Aeromonas allosaccharophila, pHP16 (KU644675) from an aquatic strain of A. caviae, pKPSH212 (KT896501), pKPSH70 (KT896500), pKPSH213.55 (KT896502), pKPSH231 (KT896503), and pKPSH169 (KT896499) from five wastewater strains of K. pneumoniae, 
pGNB2 (NC_013773) isolated from activated sludge, unnamed Salmonella enterica plasmid (MK191840), and pQnrS2_045523 (CP032896) from a clinical Enterobacter kobei strain WCHEK045523 (Table 2).

The last of the analyzed plasmids_p435_c4—was discovered in Kluyvera sp. 435 (MF457880) isolated from treated wastewater. This replicon was the most divergent from the other analyzed plasmids and showed the highest similarity to two plasmids, i.e., pJF-707 (KX946994) from clinical K. oxytoca H143640707 and pUL3AT (HE616889) isolated from Enterobacter cloacae LIM73 from hospital effluents (coverage $62 \%$, identity $100 \%$ ) (Table 2).

Comparative nucleotide analysis of the five newly identified plasmids indicated four core genes encoding: RepA (helicase), MobA-RepB (fusion gene of relaxase-primase), MobC (protein required for DNA cleavage), and a hypothetical protein. In all these plasmids, the $m o b A$ and $r e p B$ genes were fused, which was previously observed as a characteristic feature of many plasmids within all IncQ groups. Previous studies did not clearly determine if the relaxase-primase gene fusion is expressed as two separate polypeptides or as a single peptide with two domains [43]. However, there seems to exist a strong selection for these fused transcripts among the IncQ plasmids, which suggests that both processes (i.e., replication and conjugation) may be coupled. Plasmids of the IncQ group possess replication systems operating via the strand-displacement mechanism. This system consists of three genes, repBAC, which form a cluster and an intergenic region of replication initiation (oriV) containing iterons, where the replication starts [44]. In plasmids analyzed in this study, three conserved direct repeats (DR)-putative iterons-were found within the oriV regions. The consensus iteron sequence is as follows: 5'-CCCCCACGGTAACTCNNCCC-3'. The NN represents an ambiguous dinucleotide: (i) CA in plasmids p435_c4, p458_p3, p426_p3, or (ii) TC in p5.4_c4 and p115_p2. Within each oriV, the following DNA regions were identified besides iterons: (a) G+C-rich region, (b) A+T-rich region, (c) 15-bp region, highly conserved in IncQ-like plasmids (5'-CTGCGCCTAGTGGAG-3') and (d) two palindromic sequences (5'-CCGCGCCGAAGGGGCGCGG-3' and 5'-ACCCCCGGAGGGGGT-3'). The $r e p B$, repA, and $\operatorname{rep} C$ replication genes are highly similar in the identified plasmids $(95-100 \%$ of nucleotide sequence identity). However, in plasmid p435_c4, no equivalent of the $\operatorname{rep} C$ gene was identified, which suggests that the product of that gene may be delivered in trans or that the gene is unnecessary for plasmid replication. The latter hypothesis seems to be more probable, since the sequences of two other, highly similar IncQ-3 plasmids, also deprived of the $\operatorname{rep} C$ gene, were found in the NCBI database, i.e., pJF-707 (KX946994) and pUL3AT (HE616889).

The genetic module responsible for the mobilization to conjugal transfer is also highly conserved within all identified plasmids. It consists of two genes- mobA and mobC. The oriT sites of the analyzed IncQ-3 plasmids were identified based on the homology to the previously identified oriTs [30] and all 29 plasmids contain the same, highly conserved, putative 12-bp region (5'-TTACACCTTGCT- $\left.3^{\prime}\right)$ comprising an origin of transfer.

The analyzed plasmids were tested for their ability to be transferred into two hosts, E. coli DH5a (Rifr ${ }^{r}$ and Pseudmonas aeruginosa PAO1161 (Rifr), via bi- and triparental conjugation (Table S1 Supplementary Material). Interestingly, only two plasmids, p5.4_c4 and p115_p3, originally carried by Aeromonas spp. and Raoultella spp., were transferable, which is in agreement with previous findings concerning highly similar IncQ plasmids $[28,29,38]$. Transconjugants were ceftazidime-resistant, which also confirm that beta-lactamase genes carried by IncQ plasmids were truly expressed. In contrast, plasmids p426_p3, p458_p3, and p435_c4 carried by Aeromonas spp. and Kluyvera sp. were unable to be transferred via conjugation into the tested strains, although these plasmids were successfully introduced to both recipient strains by transformation (as shown in a control experiment). Therefore, we speculate that their mobilization systems may be inactive or that the plasmids need a mobilizing system different from the RK2 mating pair formation system (present in plasmid pRK2013) that was provided in the tri-parental mating.

Apart from the conserved backbone, the analyzed plasmids carry various sets of auxiliary genes, the majority of which are antibiotic resistance genes (Figure 1). The identified ARGs include $\beta$-lactam, quinolone, trimethoprim, and aminoglycoside resistance genes. The $b l a_{\mathrm{FOX}}-15$ 
gene found in p435_c4 plasmid was previously identified as a new variant of $b l a_{\text {FOx }}$ gene encoding cephalosporin-hydrolyzing class $C \beta$-lactamase (MF795087) [21]. This gene was $96 \%$ identical at the level of nucleotide sequence to bla $a_{\mathrm{FOX} 2}$ from E. coli (NG_049102), bla $a_{\mathrm{FO} 3}$ from K. oxytoca (NG_049103), and bla $_{\mathrm{FOX} 3}$ from Klebsiella pneumoniae (LC072710). The sequence of the second $\beta$-lactamase gene bla $a_{\mathrm{GES}-7}$ found in plasmids p5.4_c4 and p115_p2 was 100\% identical to those of bla $a_{\mathrm{GES}-7}$ from S. marcescens (AYD68573), bla $a_{\mathrm{GES}-7}$ from E. cloacae subsp. cloacae (ANS91868), bla $a_{\mathrm{GES}-7}$ from Pseudomonas putida (CZT31717), and bla $a_{\mathrm{GES}-7}$ from Aeromonas veronii (ADU79013). Quinolone resistance (qnrS2) genes were found in p426_p3 and p458_p3. Identical gene sequences were found in numerous strains in the NCBI database, e.g., E. coli (MT219825), A. caviae (MN477222), or Shewanella aestuarii (CP050314). Trimethoprim resistance gene $d f r B 3$ found in p5.4_c4 and p115_p2 is another widespread ARG whose sequence shows $100 \%$ identity with that of $d f r B 3$ gene from S. marcescens (MH569711, CP020502), Alcaligenes sp. (KY047417), Klebsiella aerogenes (NG_047747), E. coli (KU997026), and other bacteria. The last ARG was aminoglycoside resistance gene aac(6')ib-cr found in p115_p2. At the level of nucleotide sequence, the gene was identical with aac $\left(6^{\prime}\right) i b$-cr from K. pneumoniae (NG_047288), bla $a_{\mathrm{OXA}} / a a c\left(6^{\prime}\right)-I b$ from E. coli (FJ696404), and bla $a_{\mathrm{OXA}} / a a c\left(6^{\prime}\right)$-Ib from K. pneumoniae (AY219651).

Other identified genetic modules of the analyzed plasmids include IS4 family transposase tnp (plasmid p435_c4), ATPase subunits of an ABC transporter (p435_c4), type 3 integrases intI3 (p5.4_c4 and p115_p2), and an aerotaxis sensor receptor protein (p458_p3) (Figure 1). A summary of the identified genes, including the size of the encoded proteins, their position, and predicted function is presented in Table S2 (Supplementary Material).

\subsection{Comparative Genomics of Inc-Q3 Plasmids}

As mentioned above, the clustering proposed by Loftie-Eaton and Rawlings (2012) divides IncQ plasmids into four subgroups: IncQ-1, IncQ-2, IncQ-3, and IncQ-4, based on (i) a high level of identity of their replication modules and (ii) significant diversity of their mobilization systems. In this study, we performed comparative analysis of all known IncQ-3 representatives. Based on our searches, as of 22 March 2020, the sequences of 29 putative IncQ-3 plasmids were present in the GenBank NCBI database, including five novel replicons, identified in the course of this study (Table 1). The pangenome of all investigated IncQ-3 plasmids is small and consists of 44 genes, 10 of which are ARGs. This fact was rather expected, taking into account small plasmid sizes (5.8-13.5 kbp). Despite their small size, most of the plasmids carried antibiotic resistance genes, which makes the IncQ-3 subgroup important vectors of antibiotic resistance spread. Within the pangenome, we identified 17 singletons, including int11 (integrase class 1, KX912254), bla $a_{\mathrm{FOX}-15}$ ( $\beta$-lactamase, MF795087), bla $a_{\mathrm{KPC}-21}$ (carbapenemase, MH133192), klcA/korC anti-restriction system proteins, MH133192), 5 different transposase genes of the IS4, IS30, IS5, IS1595, and IS66 families (WP_011191341, AXK00886, AUY12324, AUY12326, AUY12328, respectively), and 7 genes encoding hypothetical proteins (AIU93996, ARD69998, ARD69994, YP_002221300, AJS09376, AYL03488, CRY94842). The pangenome analysis revealed that the core genome of the analyzed IncQ-3 plasmids is composed of only three genes, i.e., repA, mobA/repB, and $m o b C$ (Figure $2 b$ ). The core genes form a conserved cluster that is present in all IncQ-3 replicons. These genes were used for the phylogenetic analysis (Figure 2a) that revealed the presence of three main clusters of the IncQ-3 plasmids (Figure 2).

The first cluster contains 16 plasmids, including p458_p3 and p426_p3. Apart from pAER-ba17, all plasmids in this cluster carry qnrS2 gene, which encodes fluoroquinolone resistance. Plasmids in this cluster have diverse oriVs, differing in iteron number and sequence.

The second cluster contains three branches formed by nine plasmids, including p5.4_c4 and p115_p2 (Figure 2a). The first and second branch consist of three plasmids: pFECR, pAHH04, and pAB5, which carry qnrS2 genes, similarly to those in cluster I. The third separate branch of cluster II consists of six replicons, which carry various antibiotic resistance genes (conferring resistances to $\beta$-lactams, trimethoprim, and aminoglycosides) that were located within class 1 or 3 integrons. 
Interestingly, each plasmid of the second branch of cluster II carries a variant of the $b l a_{\mathrm{GES}}$ gene ( $\beta$-lactamase).

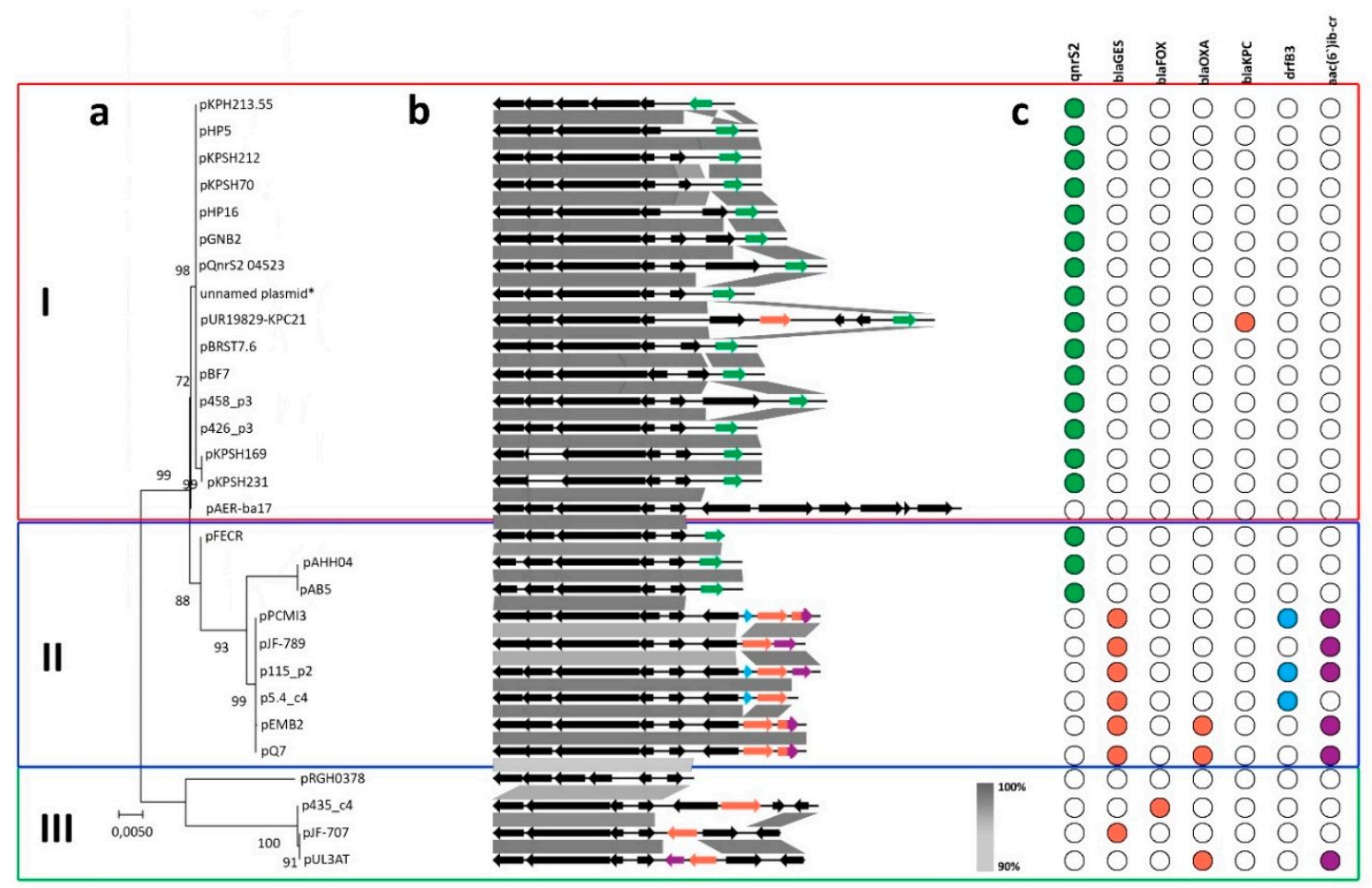

Figure 2. Comparative analyses of IncQ-3 plasmids: (a) Phylogenetic tree based on core genes of IncQ-3 replicons; (b) linear maps showing the schematic genetic structure of the circular IncQ-3 plasmids (retrieved from the NCBI database on 22 March 2020). The gray-shaded areas connect DNA regions of at least 90\% sequence identity; ARGs were colored as on panel c. (c) ARGs carried by IncQ-3 plasmids conferring resistance to: Fluoroquinolones (green), $\beta$-lactams (orange), trimethoprim (blue), and aminoglycosides (violet).

The last cluster (III) consists of four plasmids divided into two branches. The former includes p435_c4, pJF-707, and pUL3AT and the latter contains one plasmid-pRGRH0378. Characteristic features of these plasmids are: (i) Differences in the structure of oriVs and (ii) the presence of variable set of ARGs, which makes them the most heterogeneous cluster. Furthermore, the lack of repC gene was observed within three plasmids in this cluster, i.e., p435_c4, pJF-707, and pUL3AT (Figure 2). Plasmid pRGRH0378 was obtained from a rat gut metagenome from hospital sewage in Denmark (LN853034.1). The plasmid possesses repC gene and all other core genes characteristic of the rest of IncQ-3a plasmids and only one additional gene encoding a hypothetical protein. That makes pRGRH0378 not only the smallest reported plasmid of the IncQ-3 group (5.8 kbp) but also the most conserved one.

\subsection{IncQ-3 Plasmids as a Reservoir of Antibiotic Resistance Genes and Biogeography of IncQ-3 Plasmids}

Comparative genomics of all 29 known IncQ-3 plasmids showed that 27 of them carry at least one antibiotic resistance gene that confers resistance to quinolone, $\beta$-lactams, or trimethoprim (Tables 1 and 2). Two main groups of antibiotic resistance vectors were identified within investigated plasmids: (1) qnrS2-carrying plasmids that confer quinolone resistance, and (2) plasmids carrying $\beta$-lactam resistance genes-bla $a_{\mathrm{GES}}, b l a_{\mathrm{OXA}}$, and $b l a_{\mathrm{FOX}}$-comprising integron gene cassettes (Figure $2 \mathrm{c}$ ).

The qnrS2-carrying plasmid group consists of 18 replicons that have been found worldwide, mainly in wastewater [29,42] or other aqueous environments, including river water [28], hospital effluents [28], or infected fish [31,40]. These plasmids originated from diverse geographical regions, including Israel [42], Germany [29], China ([28], CP032896), Portugal (MH133192), USA (MK191840), 
Canada (MF554639), South Korea [40], and Poland (p458_p3 and p426_p3 found in this study) (Figure 3). The qnrS2 genes belong to the most prevalent plasmid-mediated quinolone resistance (PMQR) gene group. Plasmid-mediated quinolone resistance was first identified in a Klebsiella pneumoniae clinical isolate from the United States in 1998 [45]. Since then, wide dissemination of $q n r$ genes has been confirmed in both clinical and environmental strains. The dissemination is often associated with transposable elements (TEs) harbored by plasmids [46]. It was suggested that the qnrS2 gene was potentially introduced into some of the IncQ-3 plasmids by transposition [28]. In seven of the analyzed plasmids, qnrS2 is a part of a putative, nonautonomous, mobile insertion cassette, bordered by inverted repeats (IRs) and flanked by 5-bp long direct repeats (DRs). The insertion site in plasmids pAB5 [28] and pAHH04 [40] is different from that in the remaining counterparts, which suggests two independent transposition events.

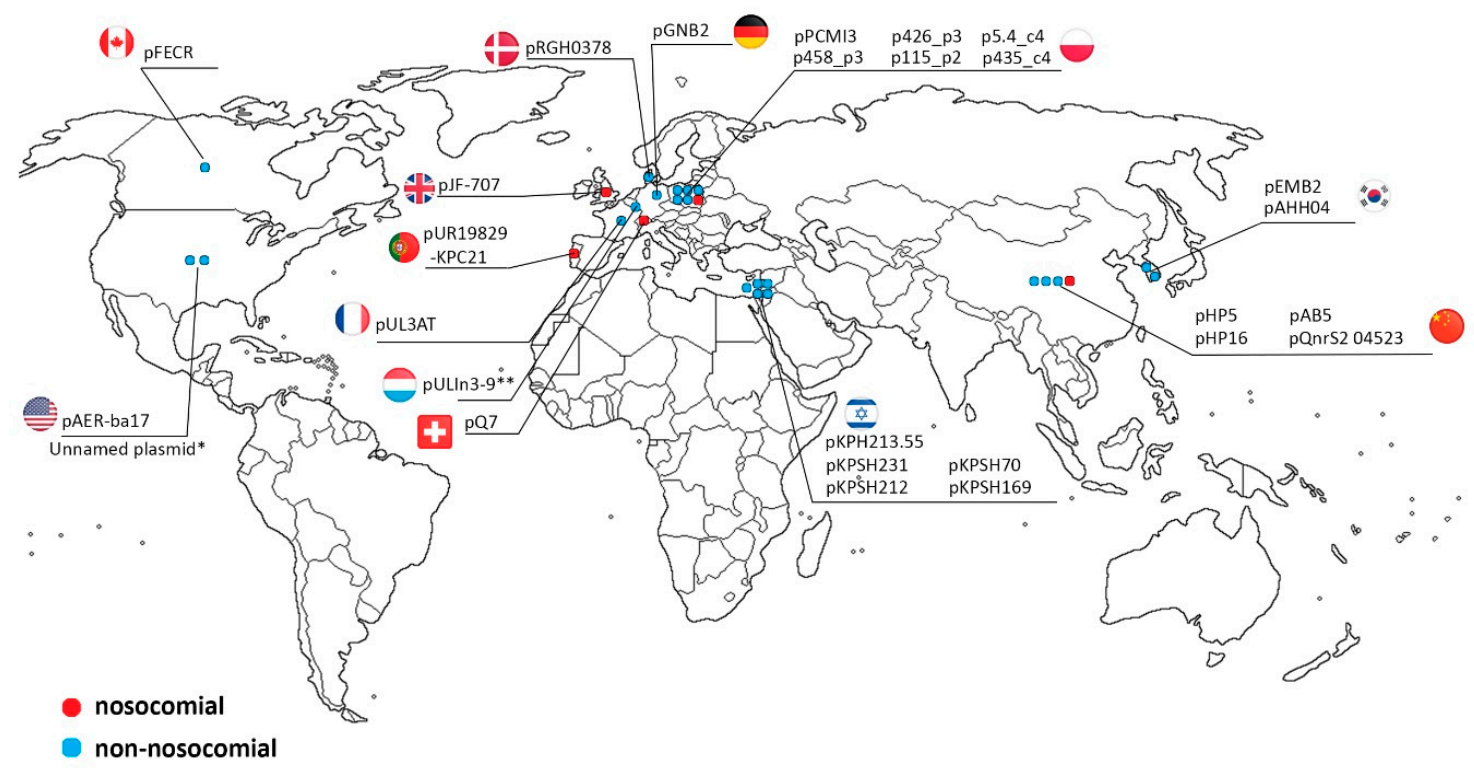

Figure 3. Biogeography of IncQ-3 plasmids: Blue dots-plasmids isolated from non-nosocomial environments; red dots-plasmids isolated from nosocomial environments.

One of the plasmids pUR19829-KPC21 (MH133192) additionally encodes a bla $a_{\mathrm{KPC}}$ gene [41]. The carbapenemase gene is located on a putative complex mobile element, which is also present in pKP1194 plasmid identified in a clinical K. pneumoniae strain (KX756453) [41].

The plasmid-mediated qnrS2 genes have been identified mainly in representatives of Enterobacteriaceae, Shewanella sp., Vibrionaceae, and Aeromonas spp. [47-51]. While the analyzed IncQ-3 plasmids were mostly isolated from Aeromonas spp. and Klebsiella spp., these replicons were also found in E. coli, Salmonella enterica sv. Typhimurium, and E. kobei (Table 2).

The second group consists of nine plasmids that carry $\beta$-lactamase genes from various groups: $b l a_{\mathrm{GES}}, b l a_{\mathrm{OXA}}$, and $b l a_{\mathrm{FOX}}$. Simultaneously, most of these plasmids carry also other ARGs, i.e., $d f r B 3$ and $a a c\left(6^{\prime}\right) i b-c r$, encoding trimethoprim and aminoglycoside resistance, respectively. The analyzed plasmids were detected in clinical and wastewater samples in diverse geographical locations, i.e., Switzerland [32], Poland (MH569711.1, this study), South Korea [37], UK (KX946994), Luxemburg [39], and France [38]. Three of the plasmids in our study p5.4_c4, p115_p2, and p435_c4 carry bla genes also within an integron. Plasmids p5.4_c4 and p115_p2 possess bla $a_{\mathrm{GES}-7}$ gene that encodes GES class A $\beta$-lactamase [52]. GES $\beta$-lactamases are known to be encoded by integron gene cassettes originating from clinical and environmental strains [53-56]. A majority of studies identified $b$ la $_{\mathrm{GES}}$ genes within class 1 integrons. In contrast, within IncQ-3 plasmids, seven harbor class 3 integrons and only one contains a class 1 integron (Tables 1 and 2). Integrons are frequently associated with 
mobile elements, such as transposons, which fosters their dissemination among bacteria. The class 3 integrons were possibly acquired by IncQ-3 plasmids through transposition, as previously suggested by Barraud et al. (2013) [38]. The putative mobile element is bordered by terminal IRs, which closely resemble IRs of the Tn3 family, and is surrounded by 5-bp long DRs. Since no transposase gene was found, it is possible that the identified DNA region may constitute a nonautonomous transposable element, which may be mobilized by a functional transposase from another TE.

Horizontal transfer of integrons by nonautonomous TEs was previously proved experimentally in the case of integron mobilization units (IMUs), which formed a composite structure identified in the IncQ-1 family plasmid, pCHE-A [57]. The integron was surrounded by terminal IRs. Providing a Tn3-family transposase in trans resulted in transposition of the composite element into another plasmid (generating 5-bp long DRs). This indicates that nonautonomous TEs may play a role in spreading of integrons and-consequently—antibiotic resistance genes among the IncQ plasmids.

\section{Materials and Methods}

\subsection{Isolation of IncQ-3 Plasmids}

Five plasmids analyzed in this study were found in 16 strains originating from "Czajka" Wastewater Treatment Plant in Warsaw, Poland. The strains belong to Aeromonas spp. or Enterobcteriaceae (Table S3). A detailed description of sample collection, bacterial isolation, sewage treatment processing, and the identified strains was provided in our previous papers [20,21]. Previously, we investigated 162 bacterial isolates exhibiting resistance to $\beta$-lactams. In 110 strains, at least one extrachromosomal replicon was found; however, a majority of strains shared common plasmid profiles, as judged from electrophoretic analysis. Thirty strains with unique plasmid profiles were selected for further analyses. Complete nucleotide sequences of their plasmids were determined from plasmids isolated in 2018. Among the sequenced plasmids, the most numerous ones were small (7.6-9.6 kb) IncQ-3 plasmids (Table 1). These plasmids have been thoroughly analyzed in this study.

\subsection{DNA Sequencing and Assembly}

The complete nucleotide sequences of the plasmids were determined using Illumina MiSeq (Illumina Inc., San Diego, CA, USA) and MinION (Oxford Nanopore, Oxford, UK) sequencers yielding around $100 \times$ sequence coverage for each plasmid. Total plasmid DNA of the strains was sequenced in the DNA Sequencing and Oligonucleotide Synthesis Laboratory (oligo.pl) at the Institute of Biochemistry and Biophysics, Polish Academy of Sciences (Warsaw, Poland). Raw reads obtained were assembled de novo into contigs and scaffolds using the Unicycler hybrid approach (Unicycler v. 0.4.6). Unicycler is open source (GPLv3) and available at github.com/rrwick/Unicycler. Final gap closure was performed by PCR amplification of DNA fragments, followed by Sanger sequencing with an ABI3730x1 Genetic Analyzer (Applied Biosystems, Waltham, MA, USA).

\subsection{Gene Annotation and Bioinformatics}

The rapid annotation of the complete nucleotide sequences of plasmids was performed with on-line MAISEN tool [58]. Additional manual annotations and preparation of plasmid files for deposition were performed using Artemis software version 16.0.0 [59]. Comparative genomic analyses were carried out with BLASTn and BLASTx tools [60]. Comparative genomic data were visualized using EasyFig software version 2.2.4. [61]. Phylogenetic analysis was performed with MEGA7 [62]. Transposable elements were identified by comparative analyses (BLASTn, BLASTx) using ISfinder database [63].

\subsection{Plasmid Mobility Testing}

Mobility (via conjugation) of the identified IncQ-3 plasmids was determined in bi- and triparental mating assays. Before the experiment, minimal inhibitory concentrations (MICs) were determined 
for chosen antibiotics according to M07-A9 guidelines of the Clinical and Laboratory Standards Institute (Table S4, Supplementary Material). Sixteen donor strains of the IncQ-3 plasmids and recipient strains were tested for plasmid-encoded resistance to the following drugs: Ceftazidime (CAZ; $128-0.5 \mu \mathrm{g} / \mathrm{mL}$ ), trimethoprim (TRI; $512-1 \mu \mathrm{g} / \mathrm{mL}$ ), ciprofloxacin (CIP; $1024-0.5 \mu \mathrm{g} / \mathrm{mL}$ ), tetracycline (TET; $512-1 \mu \mathrm{g} / \mathrm{mL}$ ), and rifampicin (RIF; $256-0.5 \mu \mathrm{g} / \mathrm{mL}$ ). Rifampicin-resistant E. coli DH5 $\alpha \mathrm{R}$ $\left(\right.$ Rif $\left.^{\mathrm{r}}\right)$, tetracycline-resistant E. coli JCB816 $\left(\right.$ Tet $\left.^{\mathrm{r}}\right)$, and Pseudomonas aeruginosa PAO1161 (Rif ${ }^{\mathrm{r}}$ ) were used as recipient strains. In triparental mating, E. coli strain DH5a with pRK2013 helper plasmid was additionally used [64]. Transconjugants were selected on Lysogeny Broth agar plates supplemented with appropriate antibiotics, as listed in Table S1 (Supplementary Material). Transconjugant identity was verified in a three-step assay: (1) Single colonies of potential transconjugants were plated on chromogenic coliform agar (Biomaxima, Poland) (E. coli-blue colonies, Aeromonas sp./Raoultella sp./Kluyvera sp.-pink colonies, P. aeruginosa-beige colonies); (2) PCR analysis with primers listed in Table S5 (Supplementary Materials) was performed using isolated plasmid DNA as a matrix; (3) plasmids from transconjugants were isolated following alkaline lysis procedure (Sambrook and Russell, 2001) and visualized by electrophoresis and DNA staining.

As a control of the conjugal transfer experiments, plasmid DNA was introduced into recipient strains via chemical transformation. Plasmid DNA was isolated from the donor strains using a classical alkaline lysis procedure [65] and introduced into E. coli DH5 $\alpha$ and P. aeruginosa PAO1 by chemical transformation $[66,67]$.

\subsection{Plasmid Sequences Accession Numbers}

The complete nucleotide sequences of plasmids were deposited in GenBank (NCBI) database under the accession numbers MT231818-MT231822 (Table 1). A complete annotation table is also available in Supplementary Materials (Table S2).

\section{Conclusions}

As the reservoirs of antibiotic-resistant bacteria, WWTPs are ideal places for horizontal gene transfer of various ARGs. IncQ plasmids belong to a group of widely distributed replicons, occurring mostly in aquatic environments, including wastewater treatment plants, hospital effluents, and clinical samples. Previously proposed classification system divides IncQ group of plasmids into four subgroups: IncQ-1, IncQ-2, IncQ-3, and IncQ-4. The aim of this study was to analyze IncQ-3 plasmids whose sequences had been deposited in the NCBI database, plus five newly identified replicons (in five Aeromonas sp., ten Raoutella sp., and one Kluyvera sp. strain) from the "Czajka" WWTP in Poland. Hos strains for these novel plasmids were isolated from wastewater at various stages of its treatment: Raw wastewater, activated sludge, or treated wastewater.

Based on phylogenetic analysis of three plasmid core genes, the identified replicons were divided into three clusters. However, all these plasmids have highly conserved backbones. The majority of the studied plasmids (27 out of 29) were vectors of ARGs and collectively carried seven different genes that encode resistance to four groups of antibiotics ( $\beta$-lactams, fluoroquinolones, trimethoprim, and aminoglycosides). IncQ-3 as vectors of antibiotic resistance genes were divided into two main groups: (I) Vectors of $q n r S 2$ gene that encodes fluoroquinolone resistance and (II) vectors of $\beta$-lactam, trimethoprim, and aminoglycoside resistance genes located within an integron.

Supplementary Materials: The following are available online at http://www.mdpi.com/2079-6382/9/9/613/s1. Table S1: Results of bi- and triparental mating assays of the identified IncQ-3 plasmids. Table S2: Genes located within the analyzed IncQ-3 plasmids. Table S3: Bacterial strains used in this study. Table S4: Results of Minimum Inhibitory Concentration (MICs) for donor and recipient strains for bi- and triparental mating assays. Table S5: Primers used in this study.

Author Contributions: Conceptualization, M.P. (Marta Piotrowska) and M.P. (Magdalena Popowska); methodology, M.P. (Marta Piotrowska) and M.P. (Magdalena Popowska); conducting research, performing the experiments, M.P. (Marta Piotrowska), R.O., C.C.; data curation, M.P. (Marta Piotrowska); writing-original draft preparation, M.P. (Marta Piotrowska), M.P. (Magdalena Popowska), C.C.; writing-review and editing, 
L.D., M.P. (Magdalena Popowska), M.P. (Marta Piotrowska), C.C.; visualization, R.O., M.P. (Marta Piotrowska); supervision, M.P. (Magdalena Popowska); project administration, M.P. (Marta Piotrowska); funding acquisition, M.P. (Marta Piotrowska) and M.P. (Magdalena Popowska). All authors have read and agreed to the published version of the manuscript.

Funding: This research was funded by the National Science Centre, Poland, grants numbers UMO-2014/15/N/NZ9/00439 and UMO-2017/25/Z/NZ7/03026.

Acknowledgments: The authors would like to thank the Drewniak and Dziewit Research Group for all their support in bioinformatics analyses, with a special thanks to Mikołaj Dziurzyński for support with the MAISEN tool and Przemysław Decewicz for sharing know-how about sequence deposition in GenBank.

Conflicts of Interest: The authors declare no conflict of interest. The funders had no role in the design of the study; in the collection, analyses, or interpretation of data; in the writing of the manuscript; or in the decision to publish the results.

\section{References}

1. Dröge, M.; Pühler, A.; Selbitschka, W. Phenotypic and molecular characterization of conjugative antibiotic resistance plasmids isolated from bacterial communities of activated sludge. Mol. Gen. Genet. 2000, 263, 471-482. [CrossRef] [PubMed]

2. Kim, S.; Yun, Z.; Ha, U.-H.; Lee, S.; Park, H.; Kwon, E.E.; Cho, Y.; Choung, S.; Oh, J.; Medriano, C.A.; et al. Transfer of antibiotic resistance plasmids in pure and activated sludge cultures in the presence of environmentally representative micro-contaminant concentrations. Sci. Total Environ. 2014, 468-469, 813-820. [CrossRef] [PubMed]

3. Marano, R.B.M.; Cytryn, E. The Mobile Resistome in Wastewater Treatment Facilities and Downstream Environments. In Antimicrobial Resistance in Wastewater Treatment Processes; John Wiley \& Sons, Ltd.: Hoboken, NJ, USA, 2017; pp. 129-155. ISBN 978-1-119-19242-8.

4. Munita, J.M.; Arias, C.A. Mechanisms of Antibiotic Resistance. Microbiol. Spectr. 2016, 4, 481-511. [CrossRef] [PubMed]

5. Partridge, S.R.; Kwong, S.M.; Firth, N.; Jensen, S.O. Mobile Genetic Elements Associated with Antimicrobial Resistance. Clin. Microbiol. Rev. 2018, 31. [CrossRef] [PubMed]

6. Perry, J.A.; Wright, G.D. The antibiotic resistance "mobilome": Searching for the link between environment and clinic. Front. Microbiol. 2013, 4, 138. [CrossRef]

7. Krzemiński, P.; Markiewicz, Z.; Popowska, M. Entry Routes of Antibiotics and Antimicrobial Resistance in the Environment. In Antibiotics and Antimicrobial Resistance Genes: Environmental Occurrence and Treatment Technologies; Hashmi, M.Z., Ed.; Emerging Contaminants and Associated Treatment Technologies; Springer International Publishing: Cham, Switzerland, 2020; pp. 1-26. ISBN 978-3-030-40422-2.

8. Di Cesare, A.; Fontaneto, D.; Doppelbauer, J.; Corno, G. Fitness and Recovery of Bacterial Communities and Antibiotic Resistance Genes in Urban Wastewaters Exposed to Classical Disinfection Treatments. Environ. Sci. Technol. 2016, 50, 10153-10161. [CrossRef]

9. Schlueter, A.; Szczepanowski, R.; Pühler, A.; Top, E. Genomics of IncP-1 antibiotic resistance plasmids isolated from wastewater treatment plants provides evidence for a widely accessible drug resistance gene pool. FEMS Microbiol. Rev. 2007, 31, 449-477. [CrossRef]

10. Carattoli, A. Plasmids and the spread of resistance. Int. J. Med. Microbiol. 2013, 303, 298-304. [CrossRef]

11. Boolchandani, M.; D'Souza, A.W.; Dantas, G. Sequencing-based methods and resources to study antimicrobial resistance. Nat. Rev. Genet. 2019, 20, 356-370. [CrossRef]

12. Yang, Y.; Li, B.; Ju, F.; Zhang, T. Exploring variation of antibiotic resistance genes in activated sludge over a four-year period through a metagenomic approach. Environ. Sci. Technol. 2013, 47, 10197-10205. [CrossRef]

13. Schlueter, A.; Krause, L.; Szczepanowski, R.; Goesmann, A.; Pühler, A. Genetic diversity and composition of a plasmid metagenome from a wastewater treatment plant. J. Biotechnol. 2008, 136, 65-76. [CrossRef] [PubMed]

14. Szczepanowski, R.; Bekel, T.; Goesmann, A.; Krause, L.; Krömeke, H.; Kaiser, O.; Eichler, W.; Pühler, A.; Schlüter, A. Insight into the plasmid metagenome of wastewater treatment plant bacteria showing reduced susceptibility to antimicrobial drugs analysed by the 454-pyrosequencing technology. J. Biotechnol. 2008, 136, 54-64. [CrossRef] [PubMed] 
15. Agga, G.E.; Arthur, T.M.; Durso, L.M.; Harhay, D.M.; Schmidt, J.W. Antimicrobial-Resistant Bacterial Populations and Antimicrobial Resistance Genes Obtained from Environments Impacted by Livestock and Municipal Waste. PLoS ONE 2015, 10, e0132586. [CrossRef] [PubMed]

16. Manaia, C.M.; Rocha, J.; Scaccia, N.; Marano, R.; Radu, E.; Biancullo, F.; Cerqueira, F.; Fortunato, G.; Iakovides, I.C.; Zammit, I.; et al. Antibiotic resistance in wastewater treatment plants: Tackling the black box. Environ. Int. 2018, 115, 312-324. [CrossRef] [PubMed]

17. Krzemiński, P.; Markiewicz, Z.; Popowska, M. Treatment Technologies for Removal of Antibiotics, Antibiotic Resistance Bacteria and Antibiotic-Resistant Genes. In Antibiotics and Antimicrobial Resistance Genes: Environmental Occurrence and Treatment Technologies; Hashmi, M.Z., Ed.; Emerging Contaminants and Associated Treatment Technologies; Springer International Publishing: Cham, Switzerland, 2020; pp. 415-434. ISBN 978-3-030-40422-2.

18. LaPara, T.M.; Burch, T.R.; McNamara, P.J.; Tan, D.T.; Yan, M.; Eichmiller, J.J. Tertiary-treated municipal wastewater is a significant point source of antibiotic resistance genes into Duluth-Superior Harbor. Environ. Sci. Technol. 2011, 45, 9543-9549. [CrossRef] [PubMed]

19. Manaia, C.; Novo, A.; Coelho, B.; Nunes, O. Ciprofloxacin Resistance in Domestic Wastewater Treatment Plants. Waterairand Soil Pollut. 2009, 208, 335-343. [CrossRef]

20. Piotrowska, M.; Przygodzińska, D.; Matyjewicz, K.; Popowska, M. Occurrence and Variety of $\beta$-Lactamase Genes among Aeromonas spp. Isolated from Urban Wastewater Treatment Plant. Front. Microbiol. 2017, 8, 863. [CrossRef]

21. Piotrowska, M.; Kowalska, S.; Popowska, M. Diversity of $\beta$-lactam resistance genes in gram-negative rods isolated from a municipal wastewater treatment plant. Ann. Microbiol. 2019, 69, 591-601. [CrossRef]

22. Lorenzo, P.; Adriana, A.; Jessica, S.; Carles, B.; Marinella, F.; Marta, L.; Luis, B.J.; Pierre, S. Antibiotic resistance in urban and hospital wastewaters and their impact on a receiving freshwater ecosystem. Chemosphere 2018, 206, 70-82. [CrossRef]

23. Sakai, H.; Komano, T. DNA replication of IncQ broad-host-range plasmids in gram-negative bacteria. Biosci. Biotechnol. Biochem. 1996, 60, 377-382. [CrossRef]

24. Guerry, P.; Van Embden, J.; Falkow, S. Molecular Nature of Two Nonconjugative Plasmids Carrying Drug Resistance Genes. J. Bacteriol. 1974, 117, 619-630. [CrossRef] [PubMed]

25. Gardner, M.N.; Deane, S.M.; Rawlings, D.E. Isolation of a New Broad-Host-Range IncQ-Like Plasmid, pTC-F14, from the Acidophilic Bacterium Acidithiobacillus caldus and Analysis of the Plasmid Replicon. J. Bacteriol. 2001, 183, 3303-3309. [CrossRef] [PubMed]

26. Loftie-Eaton, W.; Rawlings, D.E. Evolutionary Competitiveness of Two Natural Variants of the IncQ-Like Plasmids, pRAS3.1 and pRAS3.2. J. Bacteriol. 2010, 192, 6182-6190. [CrossRef] [PubMed]

27. Loftie-Eaton, W.; Rawlings, D.E. Comparative Biology of Two Natural Variants of the IncQ-2 Family Plasmids, pRAS3.1 and pRAS3.2. J. Bacteriol. 2009, 191, 6436-6446. [CrossRef] [PubMed]

28. Wen, Y.; Pu, X.; Zheng, W.; Hu, G. High Prevalence of Plasmid-Mediated Quinolone Resistance and IncQ Plasmids Carrying qnrS2 Gene in Bacteria from Rivers near Hospitals and Aquaculture in China. PLoS ONE 2016, 11, e0159418. [CrossRef]

29. Bönemann, G.; Stiens, M.; Pühler, A.; Schlüter, A. Mobilizable IncQ-related plasmid carrying a new quinolone resistance gene, qnrS2, isolated from the bacterial community of a wastewater treatment plant. Antimicrob. Agents Chemother. 2006, 50, 3075-3080. [CrossRef]

30. Loftie-Eaton, W.; Rawlings, D.E. Diversity, biology and evolution of IncQ-family plasmids. Plasmid 2012, 67, 15-34. [CrossRef]

31. Majumdar, T.; Das, B.; Bhadra, R.K.; Dam, B.; Mazumder, S. Complete nucleotide sequence of a quinolone resistance gene (qnrS2) carrying plasmid of Aeromonas hydrophila isolated from fish. Plasmid 2011, 66, 79-84. [CrossRef]

32. Poirel, L.; Carattoli, A.; Bernabeu, S.; Bruderer, T.; Frei, R.; Nordmann, P. A novel IncQ plasmid type harbouring a class 3 integron from Escherichia coli. J. Antimicrob. Chemother. 2010, 65, 1594-1598. [CrossRef]

33. Yagi, J.M.; Sims, D.; Brettin, T.; Bruce, D.; Madsen, E.L. The genome of Polaromonas naphthalenivorans strain CJ2, isolated from coal tar-contaminated sediment, reveals physiological and metabolic versatility and evolution through extensive horizontal gene transfer. Environ. Microbiol. 2009, 11, 2253-2270. [CrossRef]

34. Cyriaque, V.; Jacquiod, S.; Riber, L.; Abu Al-Soud, W.; Gillan, D.C.; Sørensen, S.J.; Wattiez, R. Selection and propagation of IncP conjugative plasmids following long-term anthropogenic metal pollution in river sediments. J. Hazard. Mater. 2020, 382, 121173. [CrossRef] [PubMed] 
35. Romaniuk, K.; Styczynski, M.; Decewicz, P.; Buraczewska, O.; Uhrynowski, W.; Fondi, M.; Wolosiewicz, M.; Szuplewska, M.; Dziewit, L. Diversity and Horizontal Transfer of Antarctic Pseudomonas spp. Plasmids. Genes 2019, 10, 850. [CrossRef] [PubMed]

36. Young, S.; Rohr, J.R.; Harwood, V.J. Vancomycin resistance plasmids affect persistence of Enterococcus faecium in water. Water Res. 2019, 166, 115069. [CrossRef] [PubMed]

37. Lee, H.J.; Jin, H.M.; Park, M.S.; Park, W.; Madsen, E.L.; Jeon, C.O. Recovery of plasmid pEMB1, whose toxin-antitoxin system stabilizes an ampicillin resistance-conferring $\beta$-lactamase gene in Escherichia coli, from natural environments. Appl. Environ. Microbiol. 2015, 81, 40-47. [CrossRef] [PubMed]

38. Barraud, O.; Casellas, M.; Dagot, C.; Ploy, M.-C. An antibiotic-resistant class 3 integron in an Enterobacter cloacae isolate from hospital effluent. Clin. Microbiol. Infect. 2013, 19, E306-E308. [CrossRef]

39. Simo Tchuinte, P.L.; Stalder, T.; Venditti, S.; Ngandjio, A.; Dagot, C.; Ploy, M.-C.; Barraud, O. Characterisation of class 3 integrons with oxacillinase gene cassettes in hospital sewage and sludge samples from France and Luxembourg. Int. J. Antimicrob. Agents 2016, 48, 431-434. [CrossRef]

40. Han, J.E.; Kim, J.H.; Choresca, C.H.; Shin, S.P.; Jun, J.W.; Chai, J.Y.; Park, S.C. A small IncQ-type plasmid carrying the quinolone resistance (qnrS2) gene from Aeromonas hydrophila. Lett. Appl. Microbiol. 2012, 54, 374-376. [CrossRef]

41. Manageiro, V.; Romão, R.; Moura, I.B.; Sampaio, D.A.; Vieira, L.; Ferreira, E.; Caniça, M. Molecular Epidemiology and Risk Factors of Carbapenemase-Producing Enterobacteriaceae Isolates in Portuguese Hospitals: Results From European Survey on Carbapenemase-Producing Enterobacteriaceae (EuSCAPE). Front. Microbiol. 2018, 9, 2834. [CrossRef]

42. Kaplan, E.; Sela, N.; Doron-Faigenboim, A.; Navon-Venezia, S.; Jurkevitch, E.; Cytryn, E. Genomic and Functional Characterization of qnr-Encoding Plasmids from Municipal Wastewater Biosolid Klebsiella pneumoniae Isolates. Front. Microbiol. 2015, 6, 1354. [CrossRef]

43. Meyer, R. Replication and conjugative mobilization of Broad Host-range IncQ plasmids. Plasmid 2009, 62, 57-70. [CrossRef]

44. Scherzinger, E.; Haring, V.; Lurz, R.; Otto, S. Plasmid RSF1010 DNA Replication In Vitro Promoted by Purified RSF1010 RepA, RepB and RepC Proteins. Available online: https:/www.ncbi.nlm.nih.gov/pmc/ articles/PMC333844/ (accessed on 9 February 2020).

45. Martínez-Martínez, L.; Pascual, A.; Jacoby, G.A. Quinolone resistance from a transferable plasmid. Lancet 1998, 351, 797-799. [CrossRef]

46. Jacoby, G.A.; Strahilevitz, J.; Hooper, D.C. Plasmid-Mediated Quinolone Resistance. Microbiol. Spectr. $2014,2$. [CrossRef] [PubMed]

47. Elnekave, E.; Hong, S.L.; Lim, S.; Hayer, S.S.; Boxrud, D.; Taylor, A.J.; Lappi, V.; Noyes, N.; Johnson, T.J.; Rovira, A.; et al. Circulation of Plasmids Harboring Resistance Genes to Quinolones and/or Extended-Spectrum Cephalosporins in Multiple Salmonella enterica Serotypes from Swine in the United States. Antimicrob. Agents Chemother. 2019, 63. [CrossRef]

48. Hu, X.; Yu, X.; Shang, Y.; Xu, H.; Guo, L.; Liang, Y.; Kang, Y.; Song, L.; Sun, J.; Yue, F.; et al. Emergence and Characterization of a Novel IncP-6 Plasmid Harboring blaKPC-2 and qnrS2 Genes in Aeromonas taiwanensis Isolates. Front. Microbiol. 2019, 10, 2132. [CrossRef] [PubMed]

49. Kim, D.-W.; Thawng, C.N.; Lee, S.H.; Cha, C.-J. Unique Features of Aeromonas Plasmid pAC3 and Expression of the Plasmid-Mediated Quinolone Resistance Genes. Msphere 2017, 2. [CrossRef]

50. Kim, H.B.; Park, C.H.; Kim, C.J.; Kim, E.-C.; Jacoby, G.A.; Hooper, D.C. Prevalence of Plasmid-Mediated Quinolone Resistance Determinants over a 9-Year Period. Antimicrob. Agents Chemother. 2009, 53, 639-645. [CrossRef] [PubMed]

51. Zhao, J.-Y.; Zhao, S.-M.; Mu, X.-D.; Xiao, Z. Genetic characterization of plasmid-mediated quinolone resistance gene qnrS2 in Pseudoalteromonas and Shewanella isolates from seawater. FEMS Microbiol. Lett. 2017, 364, fnw295. [CrossRef]

52. Gniadkowski, M. Evolution of extended-spectrum beta-lactamases by mutation. Clin. Microbiol. Infect. 2008, 14 (Suppl. 1), 11-32. [CrossRef]

53. Chudejova, K.; Rotova, V.; Skalova, A.; Medvecky, M.; Adamkova, V.; Papagiannitsis, C.C.; Hrabak, J. Emergence of sequence type 252 Enterobacter cloacae producing GES-5 carbapenemase in a Czech hospital. Diagn. Microbiol. Infect. Dis. 2018, 90, 148-150. [CrossRef] 
54. Japoni-Nejad, A.; Farshad, S.; van Belkum, A.; Ghaznavi-Rad, E. Novel cassette array in a class 1 integron in clinical isolates of Acinetobacter baumannii from central Iran. Int. J. Med. Microbiol. 2013, 303, 645-650. [CrossRef]

55. Jones-Dias, D.; Manageiro, V.; Ferreira, E.; Barreiro, P.; Vieira, L.; Moura, I.B.; Caniça, M. Architecture of Class 1, 2, and 3 Integrons from Gram Negative Bacteria Recovered among Fruits and Vegetables. Front. Microbiol. 2016, 7, 1400. [CrossRef] [PubMed]

56. Moura, Q.; Cerdeira, L.; Fernandes, M.R.; Vianello, M.A.; Lincopan, N. Novel class 1 integron (In1390) harboring blaGES-5 in a Morganella morganii strain recovered from a remote community. Diagn. Microbiol. Infect. Dis. 2018, 91, 345-347. [CrossRef] [PubMed]

57. Poirel, L.; Carrër, A.; Pitout, J.D.; Nordmann, P. Integron mobilization unit as a source of mobility of antibiotic resistance genes. Antimicrob. Agents Chemother. 2009, 53, 2492-2498. [CrossRef] [PubMed]

58. Dziurzyński, M. Drewniak \& Dziewit Research Group. Available online: http://maisen.ddg.biol.uw.edu.pl/ (accessed on 10 December 2018).

59. Carver, T.; Berriman, M.; Tivey, A.; Patel, C.; Böhme, U.; Barrell, B.G.; Parkhill, J.; Rajandream, M.-A. Artemis and ACT: Viewing, annotating and comparing sequences stored in a relational database. Bioinformatics 2008, 24, 2672-2676. [CrossRef]

60. Altschul, S.F.; Gish, W.; Miller, W.; Myers, E.W.; Lipman, D.J. Basic local alignment search tool. J. Mol. Biol. 1990, 215, 403-410. [CrossRef]

61. Sullivan, M.J.; Petty, N.K.; Beatson, S.A. Easyfig: A genome comparison visualizer. Bioinformatics 2011, 27, 1009-1010. [CrossRef]

62. Kumar, S.; Stecher, G.; Tamura, K. MEGA7: Molecular Evolutionary Genetics Analysis Version 7.0 for Bigger Datasets. Mol. Biol. Evol. 2016, 33, 1870-1874. [CrossRef]

63. Siguier, P.; Perochon, J.; Lestrade, L.; Mahillon, J.; Chandler, M. ISfinder: The reference centre for bacterial insertion sequences. Nucleic Acids Res. 2006, 34, D32-D36. [CrossRef]

64. Bartosik, D.; Baj, J.; Sochacka, M.; Piechucka, E.; Wlodarczyk, M. Molecular characterization of functional modules of plasmid pWKS1 of Paracoccus pantotrophus DSM 11072The GenBank accession number for the sequence reported in this paper is AF482428. 2002, 148, 2847-2856. Microbiology 2002, 148, 2847-2856. [CrossRef]

65. Sambrook, J.; Russell, D.W. Molecular Cloning: A Laboratory Manual; Cold Spring Harbor Laboratory: New York, NY, USA, 2001.

66. Hanahan, D.; Jessee, J.; Bloom, F.R. [4] Plasmid transformation of Escherichia coli and other bacteria. In Methods in Enzymology; Bacterial Genetic Systems; Elsevier Inc.: Amsterdam, the Netherlands, 1991; Volume 204, pp. 63-113.

67. Irani, V.R.; Rowe, J.J. Enhancement of transformation in Pseudomonas aeruginosa PAO1 by $\mathrm{Mg}^{2+}$ and heat. BioTechniques 1997, 22, 54-56. [CrossRef] 